\title{
Interaction within the Caregiver-Elderly Dyad: The Effect of a Cognitive-Behavioral Intervention
}

\section{Karina Reyes-Jarquín1, Ana Luisa González-Celis², Rebeca Guzmán-Saldaña3, Angélica Romero-Palencia ${ }^{3}$}

\footnotetext{
${ }^{1}$ Academic area of Psychology, Autonomous University of the State of Hidalgo, Hidalgo, México

${ }^{2}$ Division of Research and Graduate Studies, Faculty of Higher Education Iztacala, National Autonomous University of Mexico, Mexico City, Mexico

${ }^{3}$ Academic area of Psychology, Autonomous University of the State of Hidalgo, Hidalgo, México

Email: krjarquin@gmail.com
}

How to cite this paper: Reyes-Jarquín, K., González-Celis, A. L., Guzmán-Saldaña, R., \& Romero-Palencia, A. (2018). Interaction within the Caregiver-Elderly Dyad: The Effect of a Cognitive-Behavioral Intervention. Psychology, 9, 2673-2684.

https://doi.org/10.4236/psych.2018.912153

Received: October 12, 2018

Accepted: November 27, 2018

Published: November 30, 2018

Copyright $\odot 2018$ by authors and Scientific Research Publishing Inc. This work is licensed under the Creative Commons Attribution International License (CC BY 4.0).

http://creativecommons.org/licenses/by/4.0/

\begin{abstract}
The caregiving function implies providing help with the Basic Activities of Daily Living, or with the Instrumental Activities of Daily Living. In the case of the elderly residing in Gerontological Attention Centers, this function is provided for by gerontological specialists, which can be identified as formal caregivers. The relationship between caregiver and elderly is particularly interesting due to the physical, psychological, and health implications that the former enacts over the person receiving care. Thus, the objective of this research was to evaluate the effect of a Cognitive-Behavioral Intervention, directed towards formal caregivers of the elderly, on the interaction between the members of this dyad. This intervention was evaluated through behavioral categories, using repeated measures ANOVA and Cohen's " $\mathrm{d}$ " analyses and the results indicate that caregivers increased the execution of activities within the positive behavioral categories, while the elderly residing in the centers also showed improvements in all the evaluations despite not having received any intervention whatsoever, but, instead, as a response to the changes manifested in their caregivers.
\end{abstract}

\section{Keywords}

Interaction, Caregivers, Intervention, Cognitive-Behavioral, Elderly

\section{Introduction}

Caregiving for a dependent person, in particular an elderly, implies providing help for the execution of one or some of the Activities of Daily Living (ADL) 
(IMSERSO, 2011; Rogero-García, 2009). Among these, three types are identified: 1) Basic Activities of Daily Living (BADL), which are related to physical survival and motor coordination and functions; 2) Instrumental Activities of Daily Living (IADL), which are more complex and are focused on the actions required for the development of the individual at home and within the community; and, 3) leisure and social activities (Acosta \& González-Celis, 2009; Horgas, Wilms, \& Baltes, 1998).

Two types of caregivers can be characterized: formal and informal. A formal caregiver is the person that provides the caregiving service, whether being qualified or not, without being a relative of the dependent person, and that receives a payment or any other kind of economic benefit for his/her work. Formal caregivers pursue their professions by taking care of patients, and they receive a payment for their services. An informal caregiver is a member of the family or of the social network of the dependent person; he/she does not belong to any sanitary or social institution, and provides caregiving voluntarily, without any economic reward. Informal caregivers often have a high level of commitment, which is characterized by his/her affection towards the dependent person (Aravena et al., 2016; Centeno, 2004; Cerquera \& Galvis, 2014; Rogero-García, 2009).

Formal caregivers have attained an essential role in social and geriatric assistance (Köther \& Gnamm, 2003); nevertheless, there are risks for both parts of the formal caregiver-elderly dyad. Caregivers are faced with stressors such as lack of staff, workload overload, being in direct contact with difficult elderly persons suffering from chronical or terminal diseases, and little work autonomy, among others. This, in turn, causes caregivers to disregard their own personal needs, which provokes a reduction in adherence to medical treatments, as well as unhealthy lifestyles (Angulo \& Ramírez, 2016; Baez \& Delgado, 2013; Navarro et al., 2008). On the other hand, the main negative consequences for the elderly are the deterioration of the professional-patient relation, and a diminishment of their satisfaction, welfare, and quality of life (Gil-Monte \& Peiró, 1997; McHugh, Kutney-Lee, Cimiotti, Sloane, \& Aiken, 2011).

The professional-patient relationship, as well as the satisfaction of the latter, has been studied in the nurse-patient, doctor-patient, and surgeon-patient dyads (Contreras et al., 2008; De los Ríos \& Sánchez-Sosa, 2002; Heerdegen, Petersen, \& Jervelund, 2017; Jiménez y Villegas et al., 2003; Noor, Maria, \& Agianto, 2016; Serra-Rexach, 2003; Torres, 2010). These studies, however, have not been focused on the formal caregiver-elderly dyad.

De los Ríos and Sánchez-Sosa (2002) evaluated the effects that a nurse-patient interaction training program had on both welfare and medical recovery. The program was focused on specific behaviors, such as establishing eye contact with, greeting, offering help to, having physical proximity to, praising, smiling to, having physical contact with, scolding, shouting, and ignoring the patient. Results show that the increase of positive behaviors in the interaction between nurse and patient is related to a higher level of perceived welfare and of medical 
recovery of hospitalized patients.

However, an analysis of the effect of this kind of interventions on both members of the dyad has been neglected. For this reason, the general objective of this research was to evaluate the impact of a Cognitive-Behavioral Intervention (CBI), designed expressly for the present investigation and directed towards formal caregivers, on the interaction between the members of the caregiver-elderly dyad. This CBI was made up of six modules (relaxation, cognitive restructuring, social skills, positive reinforcement, molding, and modelling), and was evaluated through positive and negative behavioral categories.

\section{Methodology}

\subsection{Participants}

For this study, 15 formal caregiver-elderly dyads Mexicans, from two Gerontological Attention Centers (GAC) were considered; their participation was voluntary, consented, and informed.

The inclusion criteria for the caregivers were the following: having worked in the GAC for at least a year and having signed the informed consent agreement. The inclusion criteria for the elderly were: having resided in the GAC for at least a year, having received direct care from the participant caregivers (in order to assemble dyads made up of a formal caregiver and an elderly residing in the GAC), and having signed the informed consent agreement.

The caregivers group was made up of 14 women $(93.33 \%)$, and one man $(6.67 \%)$; the mean age was 46.47 years old $(\mathrm{SD}=8.92$; minimum age 29 , maximum age 61); eleven of them had gericulture studies (the term gericulture is used as a translation of the Spanish word "Gericultura", which is a technical level degree focused on elderly caregiving $(73.33 \%)$ ), 3 had social work studies (20\%), and one had nursing studies (6.67\%). The elderly group was made up of 12 women $(80 \%)$, and 3 men $(20 \%)$; the mean age was 75 years old $(\mathrm{SD}=8.51$; minimum 64, maximum 87).

\subsection{Research Design}

The research had a pretest-posttest design, with two follow ups, at 1 and 3 months each, after the end of the posttest. Both the formal caregivers and the elderly groups were evaluated at 4 different times: 1) pretest evaluation before receiving de $\mathrm{CBI}$; 2) posttest evaluation at the end of the CBI; 3 ) follow up 1, one month after the posttest; and, 4) follow up 2, three months after the posttest.

\subsection{Instruments Used}

For this research the instruments mentioned below were used.

\section{Sociodemographic datasheet}

A 30 questions survey used to acquire demographic data (age, gender, marital status, time in the institution, healthcare conditions, leisure time usage, and information regarding habits) from both samples. 


\section{Formal caregiver-elderly dyad interaction record}

The occurrence of both positive and negative behavior categories-based on the proposal made by De los Ríos and Sánchez-Sosa (2002)—was recorded on video by means of videotaping interaction episodes between the members of the dyad. For the formal caregivers the following 11 positive categories were recorded: 1) share (offering a useful object in order to fulfill either a therapeutic or a welfare support function for the elderly); 2) reward (includes approval or praise conducts by means of comments such as "you did very well", "today you look better", in an audible and kind tone of voice, accompanied or not with physical contact); 3) visual contact (holding gaze or looking at the elderly's face for as long as the physical closeness lasts, regardless of whether or not the elderly is watching the caregiver); 4) brief approaches (placing oneself close to the elderly, at a distance no larger than arm's reach, for a time lapse of less than five seconds); 5) proximity (as in the former category, but for a time lapse longer than five seconds); 6) physical contact (when the caregiver touches, pats, caresses, kisses, or hugs the elderly); 7) verbal requests (audible verbalizations that express a request or a suggestion made by the caregiver, such as "please open your mouth", "raise your arm", "put together your puzzle"); 8) smile (raising the corners of the mouth without making any sound); 9) modelling (posture movements accompanied with the corresponding descriptive verbalization, which the elderly imitates in a time lapse of less than ten seconds, such as "cough like this", "throw the ball into the basket"); 10) laugh (raising the corners of the mouth or opening the mouth congruently making a hilarious sound, accompanied or not with a comment); and, 11) ask (audible verbalizations through which the caregiver requests information from the elderly, such as "how are you this morning?", "when do you have your appointment with the doctor?", "why didn't you want to eat today?").

Furthermore, the following 3 negative behavior categories were recorded: 1) disapprove (verbalizations that imply either disagreement, negation, or an expression of disgust, or a criticism expressed by the caregiver); 2) shout (emitting a sound loud enough to cause an expression of aversion, or an aversive effect, and that contains an instruction or a comment that expresses disapproval, such as "You did so badly!", "Don't get up from bed!", "Do not leave the dining room!"); and, 3) ignore (when faced with a verbal request from the elderly, the caregiver doesn't answer within five seconds, or doesn't establish visual contact, the request is not followed through or there is no kind explanation why the request is not possible or convenient).

For the elderly, the following 10 positive categories were recorded: 1) acceptance (saying "yes", "mhm", nodding, or showing agreement with the eyes or any of the hands, as a means of showing approval or liking); 2) following instructions (conducting an action that corresponds to a kindly phrased request or instruction from the caregiver within five seconds); 3) verbal requests (includes verbalizations, or digital or manual instructions that express a need or request, 
followed by the corresponding action from the caregiver); 4) paying attention (establishing visual contact with the caregiver while he/she explains something, gives an instruction, or makes a comment); 5) praising (verbalization made by the elderly that expresses approval or gratitude towards an action conducted by the caregiver); 6) ask (audible verbalizations through which the elderly requests information from the caregiver); 7) visual contact; 8) physical contact; 9) smile; and, 10) laugh (the last four are the same as the ones described for the caregiver). Also, the occurrence of three negative categories was recorded: 1) disagreement (verbalizations that imply disagreement, as described for the caregiver); 2) shout (as described for the caregiver, but in the absence of any justifiable situation such as acute pain, extreme discomfort, or any other emergency situation); and, 3) ignore (as described for the caregiver, except for cases such as being asleep or unconscious).

The video recordings of the episodes were inspected by three independent observers, which registered the occurrence of every behavioral category. Afterwards, a Behavioral Index per Minute (BIM) was calculated for each record of every evaluated category. This BIM consisted in the calculation of a decimal number that expresses the occurrence of each category within a minute, with the purpose of making all categories comparable even when the duration of the video recordings differed.

\subsection{Devices Used}

In order to record the interaction within the dyad, a Sony Handycam DCR-HC28 recorder was used.

\subsection{Procedure}

A CBI made up of six components, directed towards formal elderly caregivers was designed. A manual for the participating formal caregiver, and another for the therapist, were made. The components of the CBI are shown below.

- Relaxation: For two sessions, through an audio recording and homework, the formal caregivers were trained in the procedures of diaphragmatic breathing, progressive muscle relaxation, and autogenous training.

- Cognitive restructuring: Based on Albert Ellis' ABCDE model (Lega, Caballo, \& Ellis, 1997), for three sessions, and with the help of homework, the formal caregivers were trained in the recognition and modification of irrational thoughts related to the elderly caregiving.

- Social skills: The caregivers were provided with the skills required to express feelings, attitudes, wishes, views, and rights adequately when interacting with partners and with the elderly. This was achieved using the role-playing technique during one session.

- Positive reinforcement, molding, and modelling: Using the role-playing technique, the formal caregivers were trained in the usage of these behavior modification techniques in order to promote in the elderly the execution of the 
Basic Activities of Daily Life independently, and to improve the interaction between the formal caregivers and the elderly. For each of these modules one session was assigned.

After the research protocol was approved by the Ethics Committee of the Psychology Degree of the Higher Studies Faculty of Iztacala, UNAM, the required permits were processed in the GACs. Afterwards, the participants were selected (formal caregivers and elderly people, with consideration of the established criteria), and they signed the informed consent agreement.

Three non-invasive video recording sessions of the interaction of the dyads where established. Such sessions were carried out in consecutive days at the same time: in the morning, when the elderly bathed and attended the dining room for breakfast. The pretest evaluation was applied on the participating formal caregivers and elderly people; afterwards, the posttest evaluation was conducted, and the follow ups were done one and three months after the CBI finished. It should be noted that in the pretest, posttest, and in the two follow ups, the interaction between the caregivers and the elderly was recorded. Finally, statistical analyses were used to observe the differences between the pretest, posttest and follow up measurements.

\section{Results}

Repeated measures ANOVA analyses were conducted for the behavioral categories evaluated in the formal caregiver-elderly interaction; furthermore, pretest-posttest, pretest-follow up 1, and pretest-follow up 2 measurements were compared in order to know if there were statistically significant differences, and to know the size of the effect of the CBI using Cohen's " $d$ ".

Table 1 and Table 2 show the results of the behavioral categories for the formal caregivers and the elderly, respectively.

In the case of the formal caregivers, it can be observed that in the 11 positive behavioral categories, and in a negative one (disapprove) there were statistically significant differences when comparing pretest, posttest, follow up 1, and follow up 2 measurements. In the categories Share $(p=.011, .004$ and .004), Visual contact $(p=.016, .001$ and .0001$)$, Proximity $(p=.046, .0001$ and .010$)$, Physical contact $(p=.021, .004$ and .0001$)$ and Ask $(p=.001, .0001$ and .0001$)$, a statistically significant increase in the score was observed from the pretest-posttest comparison onwards, and it held up to follow up 2; while, for the categories Reward $(p=.001$ and .001$)$, Brief approaches $(p=.029$ and .0001$)$, Verbal requests $(p=.001$ and .002$)$, Smile $(p=.001$ and .0001$)$, Modelling $(p=.0001$ and .0001$)$, and laugh $(p=.0001$ and .002), such increase became evident from the pretest-follow up 1 comparison onwards, and held up to follow up 2. In the negative behavioral categories Disapprove, Shout, and Ignore there were no statistically significant differences in any comparison $(p>.05)$ although the scores decreased in the categories Disapprove and Ignore. From the pretest-posttest comparison onwards, a moderate to large effect size was observed in the 11 positive behavioral 
Table 1. Analysis of variance for repeated measures (ANOVA) and Cohen's " $\mathrm{d}$ " in the behavioral categories of formal caregivers in the four evaluation times.

\begin{tabular}{|c|c|c|c|c|c|c|c|}
\hline Behavioral Categories & $\begin{array}{l}\text { Pretest } 1 \\
(\mathrm{n}=15) \\
\mathrm{M}, \mathrm{SD}\end{array}$ & $\begin{array}{l}\text { Posttest } \\
(\mathrm{n}=15) \\
\text { M, SD }\end{array}$ & $\begin{array}{l}\text { Follow-up } 1 \\
\quad(\mathrm{n}=15) \\
\mathrm{M}, \mathrm{SD}\end{array}$ & $\begin{array}{c}\text { Follow up } 2 \\
(\mathrm{n}=15) \\
\mathrm{M}, \mathrm{SD}\end{array}$ & $\begin{array}{c}F \\
\text { ANOVA }\end{array}$ & $\begin{array}{l}\text { Significant } \\
\text { Comparisons }\end{array}$ & Cohen's " $d$ " \\
\hline Share & $.49 \pm .34$ & $.93 \pm .27$ & $1.16 \pm .42$ & $1.35 \pm .6$ & $F=19.46^{* *}$ & $\begin{aligned} \text { Pretest } & <\text { Posttest } \\
\text { Pretest } & <\text { Seg1 } 1^{\star *} \\
\text { Pretest } & <\text { Seg2 } 2^{\star *}\end{aligned}$ & $\begin{array}{c}\text { Pretest }<\text { Posttest }(\mathrm{d}=1.60) \\
\text { Pretest }<\text { Seg1 }(\mathrm{d}=1.58) \\
\text { Pretest }<\text { Seg2 }(\mathrm{d}=1.42)\end{array}$ \\
\hline Reward & $.11 \pm .17$ & $.36 \pm .38$ & $.48 \pm .34$ & $.51 \pm .37$ & $F=11.96^{* *}$ & $\begin{array}{l}\text { Pretest }<\text { Seg1 } 1^{\star *} \\
\text { Pretest }<\text { Seg2 }{ }^{\star *}\end{array}$ & $\begin{array}{c}\text { Pretest }<\text { Posttest }(\mathrm{d}=.66) \\
\text { Pretest }<\text { Seg1 }(\mathrm{d}=1.09) \\
\text { Pretest }<\text { Seg2 }(\mathrm{d}=1.07)\end{array}$ \\
\hline $\begin{array}{l}\text { Visual } \\
\text { Contact }\end{array}$ & $.58 \pm .31$ & $1.04 \pm .3$ & $1.14 \pm .23$ & $1.20 \pm .43$ & $F=13.05^{\star \star}$ & $\begin{array}{c}\text { Pretest }<\text { Posttest }{ }^{\star} \\
\text { Pretest }<\text { Seg1 } 1^{\star \star} \\
\text { Pretest }<\text { Seg2 } 2^{\star *}\end{array}$ & $\begin{array}{c}\text { Pretest }<\text { Posttest }(\mathrm{d}=1.52) \\
\text { Pretest }<\text { Seg1 }(\mathrm{d}=2.38) \\
\text { Pretest }<\text { Seg2 }(\mathrm{d}=1.41)\end{array}$ \\
\hline $\begin{array}{c}\text { Brief } \\
\text { Approaches }\end{array}$ & $.51 \pm .37$ & $.83 \pm .5$ & $1.01 \pm .39$ & $1.12 \pm .36$ & $F=13.26^{* *}$ & $\begin{array}{l}\text { Pretest }<\text { Seg1 }{ }^{\star} \\
\text { Pretest }<\text { Seg2 }{ }^{* *}\end{array}$ & $\begin{array}{c}\text { Pretest }<\text { Posttest }(\mathrm{d}=.63) \\
\text { Pretest }<\text { Seg1 }(\mathrm{d}=1.28) \\
\text { Pretest }<\text { Seg2 }(\mathrm{d}=1.72)\end{array}$ \\
\hline Proximity & $.52 \pm .26$ & $.93 \pm .37$ & $.91 \pm .28$ & $1.05 \pm .36$ & $F=10.02^{\star *}$ & $\begin{array}{c}\text { Pretest }<\text { Posttest }{ }^{*} \\
\text { Pretest }<\text { Seg } 1^{\star *} \\
\text { Pretest }<\text { Seg2 } 2^{\star}\end{array}$ & $\begin{array}{c}\text { Pretest }<\text { Posttest }(\mathrm{d}=1.11) \\
\text { Pretest }<\text { Seg1 }(\mathrm{d}=1.35) \\
\text { Pretest }<\text { Seg2 }(\mathrm{d}=1.45)\end{array}$ \\
\hline $\begin{array}{l}\text { Physical } \\
\text { Contact }\end{array}$ & $.53 \pm .29$ & $.93 \pm .33$ & $.97 \pm .25$ & $1.09 \pm .26$ & $F=15.93^{\star *}$ & $\begin{aligned} \text { Pretest } & <\text { Posttest }^{*} \\
\text { Pretest } & <\text { Seg } 1^{\star *} \\
\text { Pretest } & <\text { Seg2 } 2^{\star *}\end{aligned}$ & $\begin{array}{c}\text { Pretest }<\text { Posttest }(\mathrm{d}=1.21) \\
\text { Pretest }<\text { Seg1 }(\mathrm{d}=1.73) \\
\text { Pretest }<\text { Seg2 }(\mathrm{d}=2.16)\end{array}$ \\
\hline $\begin{array}{l}\text { Verbal } \\
\text { Requests }\end{array}$ & $.62 \pm .42$ & $.87 \pm .42$ & $1.11 \pm .24$ & $1.31 \pm .47$ & $F=18.77^{* *}$ & $\begin{array}{l}\text { Pretest }<\text { Seg1 } 1^{\star *} \\
\text { Pretest }<\text { Seg2 } 2^{\star *}\end{array}$ & $\begin{array}{c}\text { Pretest }<\text { Posttest }(\mathrm{d}=.61) \\
\text { Pretest }<\operatorname{Seg} 1(\mathrm{~d}=2.02) \\
\text { Pretest }<\text { Seg2 }(\mathrm{d}=1.47)\end{array}$ \\
\hline Smile & $.34 \pm .28$ & $.70 \pm .37$ & $.88 \pm .30$ & $.97 \pm .24$ & $F=16.68^{\star *}$ & $\begin{array}{l}\text { Pretest }<\text { Seg1 } 1^{\star *} \\
\text { Pretest }<\text { Seg2 }\end{array}$ & $\begin{array}{c}\text { Pretest }<\text { Posttest }(\mathrm{d}=.95) \\
\text { Pretest }<\operatorname{Seg} 1(\mathrm{~d}=1.77) \\
\text { Pretest }<\operatorname{Seg} 2(\mathrm{~d}=2.58)\end{array}$ \\
\hline Modelling & $.01 \pm .04$ & $.16 \pm .2$ & $.31 \pm .15$ & $.26 \pm .16$ & $F=20.06^{* *}$ & $\begin{array}{l}\text { Pretest }<\text { Seg1 } 1^{\star *} \\
\text { Pretest }<\text { Seg2 }\end{array}$ & $\begin{array}{c}\text { Pretest }<\text { Posttest }(\mathrm{d}=.76) \\
\text { Pretest }<\operatorname{Seg} 1(\mathrm{~d}=1.98) \\
\text { Pretest }<\operatorname{Seg} 2(\mathrm{~d}=1.56)\end{array}$ \\
\hline Laugh & $.15 \pm .13$ & $.38 \pm .26$ & $.63 \pm .22$ & $.62 \pm .37$ & $F=14.90^{* *}$ & $\begin{array}{l}\text { Pretest }<\text { Seg } 1^{* *} \\
\text { Pretest }<\text { Seg2 } 2^{* *}\end{array}$ & $\begin{array}{c}\text { Pretest }<\text { Posttest }(\mathrm{d}=.85) \\
\text { Pretest }<\text { Seg1 }(\mathrm{d}=2.06) \\
\text { Pretest }<\text { Seg2 }(\mathrm{d}=1.26)\end{array}$ \\
\hline Disapprove & $.10 \pm .18$ & $.02 \pm .07$ & $0 \pm 0$ & $0 \pm 0$ & $F=2.35^{\star}$ & Any & Pretest $>$ Posttest $(\mathrm{d}=.90)$ \\
\hline Shout & $0 \pm .03$ & $0 \pm 0$ & $0 \pm 0$ & $0 \pm 0$ & $F=1$ & Any & Any \\
\hline Ignore & $.11 \pm .24$ & $.05 \pm .09$ & $.02 \pm .06$ & $.03 \pm .09$ & $F=.92$ & Any & $\begin{array}{c}\text { Pretest }>\text { Posttest }(\mathrm{d}=.69) \\
\text { Pretest }>\text { Seg1 }(\mathrm{d}=1.39) \\
\text { Pretest }>\text { Seg2 }(\mathrm{d}=.87)\end{array}$ \\
\hline Ask & $.58 \pm .37$ & $1.07 \pm .23$ & $1.38 \pm .30$ & $1.36 \pm .56$ & $F=16.25^{* *}$ & $\begin{array}{c}\text { Pretest }<\text { Posttest }{ }^{* *} \\
\text { Pretest }<\text { Seg1 } 1^{\star *} \\
\text { Pretest }<\text { Seg2 } 2^{\star *}\end{array}$ & $\begin{aligned} \text { Pretest } & <\text { Posttest }(\mathrm{d}=2.12) \\
\text { Pretest } & <\text { Seg1 }(\mathrm{d}=2.65) \\
\text { Pretest } & <\text { Seg2 }(\mathrm{d}=1.40)\end{aligned}$ \\
\hline
\end{tabular}

Note: ${ }^{*}$ Significant Comparisons $p \leq .05 ;{ }^{*}$ Significant Comparisons $p \leq .01$; Moderate effect. $50 \leq \mathrm{d}>.80$; Big Effect $\mathrm{d} \geq .80$.

categories, as well as in the negative category Ignore. Such effect size held up to follow up $2(\mathrm{~d}>.50)$, while the size effect for the behavioral category Disapprove was large $(d=.90)$ only in the pretest-posttest comparison. Finally, for the behavioral category Shout no intervention effect was identified since such category was not present in any of the measurements. 
Table 2. Analysis of variance for repeated measures (ANOVA) and Cohen's " $\mathrm{d}$ " in the behavioral categories of the older adult residents in the four evaluation times.

\begin{tabular}{|c|c|c|c|c|c|c|c|}
\hline Behavioral Categories & $\begin{array}{l}\text { Pretest } 1 \\
(\mathrm{n}=15) \\
\mathrm{M}, \mathrm{SD}\end{array}$ & $\begin{array}{l}\text { Posttest } \\
(\mathrm{n}=15) \\
\mathrm{M}, \mathrm{SD}\end{array}$ & $\begin{array}{l}\text { Follow-up } 1 \\
(\mathrm{n}=15) \\
\mathrm{M}, \mathrm{SD}\end{array}$ & $\begin{array}{l}\text { Follow-up } 2 \\
(n=15) \\
M, S D\end{array}$ & $\begin{array}{c}F \\
\text { ANOVA }\end{array}$ & $\begin{array}{c}\text { Significant } \\
\text { Comparisons }\end{array}$ & Cohen's "d" \\
\hline Acceptance & $.60 \pm .33$ & $.83 \pm .26$ & $1.02 \pm .44$ & $1.06 \pm .51$ & $F=7.9^{* *}$ & Pretest $<\operatorname{Seg} 1^{*}$ & $\begin{array}{c}\text { Pretest }<\text { Posttest }(\mathrm{d}=.88) \\
\text { Pretest }<\text { Seg1 }(\mathrm{d}=.95) \\
\text { Pretest }<\text { Seg2 }(\mathrm{d}=.89)\end{array}$ \\
\hline $\begin{array}{l}\text { Following } \\
\text { Instructions }\end{array}$ & $.60 \pm .31$ & $.94 \pm .35$ & $1.05 \pm .31$ & $1.24 \pm .58$ & $F=13.48^{\star *}$ & $\begin{array}{c}\text { Pretest }<\text { Posttest* } \\
\text { Pretest }<\text { Seg1 } 1^{* *} \\
\text { Pretest }<\text { Seg2 } 2^{* *}\end{array}$ & $\begin{array}{c}\text { Pretest }<\text { Posttest }(\mathrm{d}=.97) \\
\text { Pretest }<\text { Seg1 }(\mathrm{d}=1.43) \\
\text { Pretest }<\text { Seg2 }(\mathrm{d}=1.09)\end{array}$ \\
\hline Visual Contact & $.59 \pm .42$ & $.88 \pm .27$ & $1.08 \pm .29$ & $1.15 \pm .58$ & $F=8.47^{* *}$ & Pretest $<$ Seg $1^{\star}$ & $\begin{array}{c}\text { Pretest }<\text { Posttest }(\mathrm{d}=1.06) \\
\text { Pretest }<\text { Seg1 }(\mathrm{d}=1.62) \\
\text { Pretest }<\operatorname{Seg} 2(\mathrm{~d}=.95)\end{array}$ \\
\hline $\begin{array}{l}\text { Physical } \\
\text { Contact }\end{array}$ & $.50 \pm .45$ & $.85 \pm .3$ & $1.12 \pm .3$ & $1.04 \pm .33$ & $F=15.41^{\star *}$ & $\begin{array}{l}\text { Pretest }<\text { Seg1 } 1^{*} \\
\text { Pretest }<\text { Seg2 } 2^{*}\end{array}$ & $\begin{array}{c}\text { Pretest }<\text { Posttest }(\mathrm{d}=1.13) \\
\text { Pretest }<\text { Seg1 }(\mathrm{d}=2.00) \\
\text { Pretest }<\text { Seg2 }(\mathrm{d}=1.59)\end{array}$ \\
\hline $\begin{array}{l}\text { Verbal } \\
\text { Requests }\end{array}$ & $.60 \pm .26$ & $.83 \pm .33$ & $.92 \pm .34$ & $1.08 \pm .38$ & $F=15.57^{\star *}$ & Pretest $<$ Seg $2^{*}$ & $\begin{array}{c}\text { Pretest }<\text { Posttest }(\mathrm{d}=.72) \\
\text { Pretest }<\text { Seg1 }(\mathrm{d}=.94) \\
\text { Pretest }<\text { Seg2 }(\mathrm{d}=1.26)\end{array}$ \\
\hline Smile & $.33 \pm .28$ & $.75 \pm .29$ & $.67 \pm .29$ & $.80 \pm .3$ & $F=17.44^{\star \star}$ & $\begin{array}{l}\text { Pretest-Posttest } \\
\text { Pretest }<\text { Seg1 } 1^{* \star} \\
\text { Pretest }<\text { Seg2 } \\
\text { (** }\end{array}$ & $\begin{array}{c}\text { Pretest }<\text { Posttest }(\mathrm{d}=1.44) \\
\text { Pretest }<\text { Seg1 }(\mathrm{d}=1.17) \\
\text { Pretest }<\text { Seg2 }(\mathrm{d}=1.51)\end{array}$ \\
\hline $\begin{array}{c}\text { Paying } \\
\text { Attention }\end{array}$ & $.69 \pm .28$ & $.91 \pm .42$ & $1.2 \pm .29$ & $1.33 \pm .47$ & $F=13.11^{* *}$ & $\begin{array}{l}\text { Pretest }<\text { Seg1 }{ }^{\star *} \\
\text { Pretest }<\text { Seg2 }{ }^{\star}\end{array}$ & $\begin{array}{c}\text { Pretest }<\text { Posttest }(\mathrm{d}=.50) \\
\text { Pretest }<\text { Seg1 }(\mathrm{d}=1.72) \\
\text { Pretest }<\text { Seg2 }(\mathrm{d}=1.33)\end{array}$ \\
\hline Laugh & $.25 \pm .27$ & $.46 \pm .36$ & $.64 \pm .34$ & $.67 \pm .24$ & $F=10.92^{* *}$ & $\begin{array}{l}\text { Pretest }<\text { Seg } 1^{* *} \\
\text { Pretest }<\text { Seg2 } 2^{\star}\end{array}$ & $\begin{array}{c}\text { Pretest }<\text { Posttest }(\mathrm{d}=.57) \\
\text { Pretest }<\text { Seg1 }(\mathrm{d}=1.14) \\
\text { Pretest }<\text { Seg2 }(\mathrm{d}=1.69)\end{array}$ \\
\hline Praising & $.02 \pm .08$ & $.08 \pm .14$ & $.22 \pm .2$ & $.23 \pm .22$ & $F=6.64^{\star *}$ & Pretest $<\operatorname{Seg} 1^{\star}$ & $\begin{array}{l}\text { Pretest }<\text { Seg1 }(\mathrm{d}=.98) \\
\text { Pretest }<\text { Seg2 }(\mathrm{d}=.94)\end{array}$ \\
\hline Disagreement & $.12 \pm .17$ & $.06 \pm .1$ & $.03 \pm .1$ & $.06 \pm .12$ & $F=1.59$ & Any & $\begin{array}{c}\text { Pretest }>\text { Posttest }(\mathrm{d}=.54) \\
\text { Pretest }>\text { Seg1 }(\mathrm{d}=.79)\end{array}$ \\
\hline Shout & $.02 \pm .08$ & $0 \pm 0$ & $0 \pm 0$ & $.01 \pm .03$ & $F=.84$ & Any & Any \\
\hline Ignore & $.18 \pm .34$ & $.04 \pm .08$ & $.02 \pm .06$ & $.04 \pm .1$ & $F=1.67$ & Any & $\begin{aligned} \text { Pretest } & >\text { Posttest }(d=1.69) \\
\text { Pretest } & >\text { Seg1 }(d=2.44) \\
\text { Pretest } & >\text { Seg2 }(d=1.36)\end{aligned}$ \\
\hline Ask & $.54 \pm .29$ & $1.01 \pm .19$ & $1.17 \pm .21$ & $1.31 \pm .49$ & $F=16.23^{* *}$ & $\begin{array}{l}\text { Pretest-Posttest } \\
\text { Pretest }<\text { Seg1 } 1^{* *} \\
\text { Pretest }<\text { Seg2 } 2^{* *}\end{array}$ & $\begin{aligned} \text { Pretest } & <\text { Posttest }(\mathrm{d}=2.42) \\
\text { Pretest } & <\operatorname{Seg} 1(\mathrm{~d}=2.92) \\
\text { Pretest } & <\operatorname{Seg} 2(\mathrm{~d}=1.55)\end{aligned}$ \\
\hline
\end{tabular}

Note: ${ }^{*}$ Significant Comparisons $p \leq .05 ;{ }^{* *}$ Significant Comparisons $p \leq .01$; Moderate effect $.50 \leq \mathrm{d}>.80$; Big Effect $\mathrm{d} \geq .80$.

Now, for the elderly, it was observed that in 10 of the positive behavioral categories there were statistically significant differences when comparing the pretest, posttest, follow up 1 , and follow up 2 measurements $(p<.05)$. In the behavioral categories Following instructions $(p=.018, .001$ and .008$)$, Smile $(p$ $=.004, .0001$ and .0001$)$, and Ask ( $p=.0001, .0001$ and .006$)$, a statistically significant increase in the scores was observed from the pretest-posttest comparison onwards, and it held up to follow up 2; while, for the categories Physical 
contact $(p=.019$ and .028$)$, Paying attention $(p=.003$ and .011$)$, and Laugh ( $p$ $=.0001$ and .013$)$, such increase, which is statistically significant, becomes evident from the pretest-follow up 1 comparison onwards, holding up to follow up 2 . For the categories Acceptance $(p=.070)$, Visual contact $(p=.042)$, and Praise $(p=.021)$, a statistical significance was found in the pretest-follow up comparison. In the negative behavioral categories Disagreement, Shout, and Ignore there was no statistically significant difference, even though the scores were lower in all three categories $(p>.05)$. From the pretest-posttest comparison onwards, a moderate to large effect size of the intervention was observed in 10 out of the 11 positive behavioral categories (with the exception of Praise), as well as in the negative behavioral category Ignore. Such effect held up to follow up 2 ( $d>.050)$. For the behavioral category Praise, the size of the effect was large from the pretest-follow up 1 comparison onwards ( $d=.98$ and .94). Finally, in the behavioral categories Disagree and Shout, no effect of the intervention was observed (d $<.050)$.

\section{Discussion}

The majority of the studies on caregiving have been conducted on populations of elderly people and nurses; however, gericultists have been neglected, therefore, this population was taken into consideration in this study. According to Heerdegen, Petersen, and Jervelund (2017), the patient's characteristics influence the general score of the attention, for they allow medical attention providers to adapt to vulnerable groups of patients and to address specific efforts when planning and prioritizing the initiatives destined to improve the attention quality using the patient's experience.

The elderly have greater needs and require a closer attention; thus, the satisfaction of these patients is obtained as a result of a humane, individualized, and affable treatment, which makes them feel unique because their particular needs are attended to, and their welfare is achieved (Contreras et al., 2008).

Because of the aforementioned, this CBI directed towards caregivers was designed. The caregivers increased the execution of positive behavioral categories, showing a statistical and clinically significant improvement from the posttest up to follow up 2, in the behavioral categories Share, Visual contact (which occurs when the caregiver holds his/her gaze with the elderly or looks into the elderly's face), Proximity (which speaks of the physical closeness between the caregiver and the elderly for more than five seconds), and Physical contact (when the caregiver touches, pats, caresses, kisses, or hugs the elderly). This, as a whole, speaks of a more personal and affective closeness towards the individuals in charge of their caring. Finally, the caregivers also increased the behavioral category Ask (which refers to audible verbalizations through which the caregiver requests information from the elderly, and shows an increase in interest towards him/her).

The elderly residing in GACs also showed significant statistical and clinical improvement in all evaluations even though they didn't receive any intervention 
whatsoever, but as a response to the change manifested by their caregivers. The behavioral categories that showed improvement were: Following Instructions (which is a direct response to a request made by the formal caregivers); Smile (which refers to an affective response towards their caregivers); and Ask (which indicates audible verbalizations through which the elderly requests information from the caregiver). In this last behavioral category, the improvement is similar to the one shown by the caregivers, which reflects the increase of verbal interaction between caregivers and the elderly.

It is worth mentioning that in the rest of the positive behavioral categories there was an increase in execution in both groups. Even though, occasionally, such improvement did not reach statistical significance, there was always clinical significance. Regarding the negative behavioral categories, disapprove, shout, and ignore, for the case of the caregivers, and disagree, shout, and ignore, for the elderly, the occurrence rate was low from the pretest evaluation onwards, and the improvement (diminishment of the rate of occurrence) did not reach statistical significance. Nevertheless, both groups showed a moderate to large effect size for the behavioral category Ignore. These findings coincide with those of De los Ríos and Sánchez-Sosa (2002), who designed an intervention directed towards nurses in an intensive care unit of a public hospital with the purpose of inciting positive attention behaviors in nurses, and of evaluating the effect of these modifications on the patients. The authors found that all positive behaviors increased, that the medical recovery of the patients benefitted, and the efficacy of the nurses in terms of clinical competence increased. All of this suggests that nurse-patient interaction, as well as medical efficiency, can be improved with this kind of interventions.

This study was conducted in Gerontological Attention Centers; thus the conclusions regarding assistance or sanitary centers' quality, stated by Jiménez y Villegas et al. (2003) are deemed relevant. In these centers an integral quality that includes diagnostic, therapeutic, or rehabilitating processes quality, as well as perceived quality (which is determined by user satisfaction parameters such as good treatment, respect, information, continuity and comfort) should be expected.

Finally, an increase in the number of participants, as well as an individual evaluation of the effects of the CBI on each of its components is suggested as a future research line in order to single out the most powerful components, and to improve the caregiver-elderly interaction.

\section{Conflicts of Interest}

The authors declare no conflicts of interest regarding the publication of this paper.

\section{References}

Acosta, A., \& González-Celis, A. (2009). Actividades de la vida diaria en adultos mayores: la experiencia de dos grupos focales. Psicología y Salud, 19, 289-293. 
Angulo, H., \& Ramírez, Q. (2016). Relación entre la calidad de vida en salud y la carga física en cuidadores de personas con enfermedad de Alzheimer. Revista Colombiana de Salud Ocupacional, 6, 18-23.

Aravena, C., Spencer, S., Verdugo, H., Flores, C., Gajardo, J., \& Albala, B. (2016). Calidad de vida en cuidadores informales de personas con demencia: una revisión sistemática de intervenciones psicosociales. Revista Chilena de Neuro-Psiquiatría, 54, 328-341. https://doi.org/10.4067/S0717-92272016000400008

Baez, G., \& Delgado, A. (2013). Predictores de dependencia en mayores de 65 años: Una revisión sistemática. Escritos de Psicología, 6, 25-33. https://doi.org/10.5231/psy.writ.2013.2010

Centeno, S. (2004). Cuidar a los que cuidan. Qué y cómo hacerlo. España: Formación Alcalá.

Cerquera, C., \& Galvis, A. (2014). Efectos de cuidar personas con Alzheimer: un estudio sobre cuidadores formales e informales. Pensamiento Psicológico, 12, 149-167. https://doi.org/10.11144/Javerianacali.PPSI12-1.ecpa

Contreras, N., Coronado, M., López, V., Aguilar, H., Félix, A., \& Vega, A. (2008). Satisfacción con el cuidado de Enfermería del adulto mayor hospitalizado. Revista Enfermería Universitaria ENEO-UNAM, 5, 14-20.

De los Ríos, C., \& Sánchez-Sosa, J. (2002). Well-Being and Medical Recovery in the Critical Care Unit: The Role of the Nurse-Patient Interaction. Salud Mental, 25, 21-31.

Gil-Monte, P., \& Peiró, J. (1997). Desgaste psíquico en el trabajo: El síndrome de quemarse. España: Síntesis.

Heerdegen, A., Petersen, G., \& Jervelund, S. (2017). Determinants of Patient Satisfaction with Cancer Care Delivered by the Danish Healthcare System. Cancer, 1, 1-9. https://doi.org/10.1002/cncr.30673

Horgas, A., Wilms, H., \& Baltes, M. (1998). Daily Life in Very Old Age. Everyday Activities as Expression of Successful Aging. The Gerontologist, 38, 556-567. https://doi.org/10.1093/geront/38.5.556

IMSERSO (2011). Envejecimiento Activo. Libro Blanco. Madrid: Instituto de Mayores y Servicios Sociales.

Jiménez y Villegas, M., Ortega, V., Cruz, A., Cruz, C., Quintero, B., Mendoza, R., Antúnez, R., Solís, P., \& Hernández, T. (2003). Satisfacción del usuario como indicador de calidad. Revista Mexicana de Enfermería Cardiológica, 11, 58-65.

Köther, I., \& Gnamm, E. (2003). Manual de geriatría. El cuidado de las personas mayores. Madrid: Editex.

Lega, L. I., Caballo, V. E., \& Ellis, A. (1997). Teoría y práctica de la terapiaracionalemotivo-conductual. Madrid: Siglo XXI.

McHugh, M., Kutney-Lee, A., Cimiotti, J., Sloane, D., \& Aiken, L. (2011). Nurses' Widespread Job Dissatisfaction, Burnout, and Frustration with Health Benefits Signal Problems for Patient Care. Health Affairs, 30, 202-210. https://doi.org/10.1377/hlthaff.2010.0100

Navarro, E., Calero, M., López, A., Gómez, A., Torres, I., \& Calero, M. (2008). Nivel de independencia en la vida diaria y plasticidad cognitiva en la vejez. Escritos de Psicología, 2, 74-84.

Noor, S., Maria, I., \& Agianto (2016). Therelationshipbetweencaring, comfort, and patientsatisfaction in theemergencyroom, Ratu Zalecha Hospital, south Kalimantan, Indonesia. Belitung Nursing Journal, 2, 156-163.

Rogero-García, J. (2009). Distribución en España del cuidado formal e informal a las 
personas de 65 y más años en situación de dependencia. Revista Española de Salud Pública, 3, 393-405. https://doi.org/10.1590/\$1135-57272009000300005

Serra-Rexach, J. (2003). Comunicación entre el paciente anciano y el médico. Anales de Medicina Interna, 20, 57-58. https://doi.org/10.4321/S0212-71992003000200001

Torres, C. (2010). Percepción de la calidad del cuidado de enfermería en pacientes hospitalizados. Avances en Enfermería, 28, 98-110. 